\title{
Novel Availability and Performance Ratio for Internal Transportation and Manufacturing Processes in Job Shop Company
}

\author{
Perumal Puvanasvaran ${ }^{1}$ (D), Yong Siang Teoh $^{1}$ iD, Teruaki Ito ${ }^{2}$ iD \\ ${ }^{1}$ Universiti Teknikal Malaysia Melaka (Malaysia) \\ ${ }^{2}$ The University of Tokushima (Japan) \\ punesh@yahoo.com,ysteoh1987@,hotmail.com, tito@tokushima-u.ac.jp
}

Received: October 2018

Accepted: May 2019

\section{Abstract:}

Purpose: Purpose of this study includes the quantification of the impact of transportation efficiency onto the workstations the transportation serves in term of throughput and total lead time elapsed by product. Besides, it aims to synchronize the capacity available among workstations throughout a production line by studying the upper limit of throughput could be afforded by each workstation as well as their connection with each other. This study is also done on the purpose of promoting fulfillment of customer demand at shorter delivery time and minimal equipment utilization. Investigation on implementation of Overall Equipment Effectiveness (OEE) in an aerospace part-manufacturing company is studied to track out the potential opportunities to be improved.

Design/methodology/approach: Site observation is conducted on all the five manufacturing workstations in the aforementioned aerospace part manufacturing company. Time data of both automated processes and manual processes are collected and they are used to construct simulation model. From that, various scenarios of transportation efficiency are simulated in Experiment 1. In addition, Experiment 2 is also set to examine the maximum capacity of each workstation. All of these are to highlight the relationship between workstation and processes and to verify the condition of imbalanced capacity among workstations in the company. In short, this has necessitated the integration of workstation and transportation activities within the company. These are followed by proposal of measures to quantify the wastes identified.

Findings: The paper finds that implementation of OEE alone does not consider the reasonability of customer demand fulfillment. The results show that both transportation efficiency and imbalanced capacity throughout production system are not emphasized by OEE implementation in the case company. Therefore, responsibility of all workstations and transportation process in delivering demand on time are quantified. Transportation process which serves as the connectors of manufacturing processes is quantified and monitored by proposed Transportation Measure (TM) whereas workstations are measured using novel availability and performance ratio.

Research limitations/implications: Future research should be conducted to examine the impact of other station within a company such as warehouse and logistic department to the performance of equipment and materials in manufacturing workstation. Besides, the material availability as well as the skills or performance of man power could be further incorporated into the measures to consider all the entities involved in manufacturing processes.

Practical implications: The proposed availability and performance ratio for both transportation and manufacturing processes, which are related to each other, help in promoting better effectiveness of production system in terms of production amount and lead time. Besides, reasonable utilization equipment 
and minimal consumption of material are incorporated in the measures to promote Lean way in fulfilling customer demand. The effectiveness of entire production line is examined as a unity with joint responsibility under varying transportation efficiency and cycle time of each workstation. Both measures could be implemented together to optimize the production system and quantify the hidden wastes which are neglected in the OEE implementation.

Originality/value: The novel availability and performance ratio are proposed to consider customer demand, historical equipment utilization and Takt time of each workstation to examine the possibility and reasonability of demand fulfillment. This prevents both over-processing and overproduction issues which are invisible in OEE. Furthermore, delay propagation throughout production system and interrelationship between processes are quantified under transportation measure. Other novelty of the paper is that it monitors the waiting time and lead time spent in each workstation at the same time considering utilization of workstation. The proposed Transportation Measure (TM) aims to reduce the queue length and waiting time at destination workstation at minimal utilization of forklift. It also promotes less capacity investment in transportation and prioritizes its scheduling according to urgency of destination workstation.

Keywords: availability, performance ratio, transportation efficiency, takt time, integration between processes, customer demand

\section{To cite this article:}

Puvanasvaran, P., Teoh, Y.S., \& Ito, T. (2020). Novel availability and performance ratio for internal transportation and manufacturing processes in job shop company. Journal of Industrial Engineering and Management, 13(1), 1-17. https://doi.org/10.3926/jiem.2755

\section{Introduction}

Performance measurement is always important to management because it identifies the gap between current performance and desired performance and enables company to initiate progress towards closing the gaps (Samad, Hossain \& Major, 2012). It should provide context and meaning, such as insight into future performance and estimation of the time to failures, so that the right personnel could respond accordingly (Lee, Lapira, Bagheri \& Kao, 2013). Customer demand, for instance, should be considered at the very first step and synchronized with every part of operation to ensure smooth flow of production. Demand division and order placement in advance are among the options for the better production planning (Colares, n.d.).

Preparation and execution of production plans on shop floor should include performance indicators for parameter optimization, minimization of the impact from uncertainties and proactive implementation of solution to prevent performance loss (Lee et al., 2013; Mugwindiri, Nyemba, Madanhire \& Mushonga, 2013; Gansterer, Almeder \& Hartl, 2014). Besides, utilization of the manufacturing facilities has been selected as the Key Performance Index (KPI) to be considered at most of the time to attain optimum operation of plant (Gansterer, Almeder \& Hartl, 2014; Ponsignon \& Mönch, 2014; Helo, 2000). Management concentrates on the important data generated such as the capacity available and fulfillment of customer demand and excel to the benefits of company (Mugwindiri et al., 2013).

Examination on the capacity available helps to reduce the buffer inventories which are normally required to protect its downstream production from any possible breakdown. Consequently, shorter waiting time of jobs in queues due to less amount of buffer inventories and its corresponding shorter lead time will increase the competitiveness of company in term of flexibility and delivery (Afefy, 2013). It can be said that both utilization of manufacturing facility and fulfillment of customer demand are related to each other. 
In addition, issues such as unreliable downstream capacity and inefficient flow of Work In Progress (WIP) within production system have been neglected. This leads to excessive consumption of materials and delayed delivery of product to customer site even though the operation of machine in each process completes within the standard duration without any delay. Therefore, big picture of the information flow and importance of focusing on the overall performance and availability of capacity are required especially when the market is full with fluctuation of demand on multiple version of product.

Transportation, as the connecting part of two or more consecutive processes, should be quantified and monitored from time to time. Poor delivery capability is the by-product from the failure to adopt integration between operation and logistic function (Fawcett, Calantone \& Smith, 1997). From the perspective of internal integration, the logistics operation itself could be the transportation activities which are carried out within production system from one process to another. In short, it is a common practice to emphasize solely on the manufacturing environment which is controllable and internal within a company in order to minimize the error of estimation.

\section{Literature Review}

This section contains all the related review of OEE which comprises of job shop problem, introduction and application of OEE as well as its modifications. The research on previous similar studies and journals had been done. The concept from those studies are gathered and summarized in this section to simplify the overall idea of the related topics so that it could be used as supportive materials of the findings and conclusion made.

\subsection{Job Shop Problem}

Job shop has to deal with the release methods and workload control especially in high-variety flow and job shops with bottlenecks (Thürer, Stevenson, Silva \& Qu, 2017). Visibility for the future load is not ensured because shop's workload is determined randomly without review and planning activities (Salegna \& Park, 1996). Roser, Lorentzen and Deuse (2014) proposed that by observing the status of process and inventories in a flow lines, the direction of bottleneck could be detected in a dynamic system. On the other hand, Gan and Chong (2014) had selected two bottleneck candidates with highest utilization and longest wait time in buffer. The study states that bottleneck process is at upstream when a process is starved or waiting for part whereas blocking phenomena indicates that the bottleneck must be downstream.

Yuan and Graves (2016) formulate and implement a non-linear optimization model to set optimal production lot sizes and lead time as the tactical decision in make-to-stock job stock. Performance measures such as lead time, percentage tardy and mean tardiness against the throughput time are compared most of the time regardless of the severity of bottleneck. On the other hand, tardiness and earliness are considered in a study by Huang, Yang and Cheng (2013) have proven that good scheduling approach can lead to cost reduction due to shorter completion time, reduction in storage space requirement and increase in equipment utilization.

Besides, make span, machine load balance and mean waiting time of jobs are also evaluated to investigate the interaction between flexibility and scheduling performance of manufacturing job shops (Baykasoğlu \& Özbakır, 2008). Make span would decrease with the increment of flexibility level. Moreover, machine flexibility is more critical than the process plan flexibility in terms of the impact onto the job shop performance. In order to achieve shorter lead time and fewer inventories, Cuatrecasas-Arbós, Fortuny-Santos, Ruiz-de-Arbulo-López and Vintró-Sanchez (2015) suggested conditions such as smaller lot size, reduced setup time and production run, as well as making the first workstation to wait for some duration and balancing of process to synchronize the process.

Benttaleb, Hnaien and Yalaoui (2016) aimed to minimize the makespan of a two-machine job shop with availability constraint on one machine. The unavailable period of the machine is known in advance and fixed under the deterministic case. The Jackson's algorithm (Jackson, 1956) gives optimal solution only when the in-availability period is located at the beginning or end of horizon. One of the examples of job shop is the hospital. Chiarini (2013) had aimed at reduction of patient transportation inside a large hospital using Lean thinking tools and logistic solutions. The measures used include the distance covered and costs related to hospital staff. 


\subsection{Application of Overall Equipment Effectiveness (OEE)}

Overall Equipment Effectiveness (OEE) implementation which quantifies six big losses in the measure including pursuit of ideal cycle time, minimal quality defect as well as less idle capacity. It serves as an indicator to monitor, minimize and improve any detected wastes which is similar to Lean production. Besides, Overall Equipment Effectiveness (OEE) is a hierarchy of metric serves as driver of improvement and focuses on inefficiencies in manufacturing process such as wasted time when machine is not in operation, and is usually used to measure effectiveness of Total Productive Maintenance (TPM) via comparison with the world standard of OEE (Nakajima, 1988; Bamber, Castka, Sharp \& Motara, 2003; Chong, Ng \& Goh, 2015; Ramlan, Ngadiman, Omar \& Yassin, 2015). With the multiplication of availability, performance rate and quality rate, OEE tends to reduce six major production losses as shown in Figure 1 and also to serve as an indicator of process improvement activities (Dal, Tugwell \& Greatbanks, 2000; Zammori, Braglia \& Frosolini, 2011)

In general, availability measures the portion of lost production due to downtime losses over the amount of time a machine which is available for production. Downtime comprises of planned and unplanned downtime. Another factor named performance rate compares real production output to the theoretical output. It considers the speed loss and any causes that contributes to slower operation speed than the maximum possible speed. On the other hand, quality factor considers the rate of rejected item due to quality defect, the produced pieces that do not meet quality standard and wastages which require rework (Ramlan et al., 2015).

Besides, study identifies those machines which work individually using OEE so that the machine with lowest OEE value signifies the place where TPM resources should focus on (Zammori, 2015). This is similar to Adanna and Shantharam (2013) considered the process with most amount of time consumed for the experimentation and implementation of SMED to improve the setup process. Besides, it is recommended to carry out observation to identify the losses or inefficiency within the process to be studied, and sort out the significant few using Pareto chart so that the focal point of improvement could be on the step where most of the speed losses occur (Benjamin, Marathamuthu \& Murugaiah, 2015). In short, relations between workstations should be considered to improve the effectiveness of the entire line with least resources.

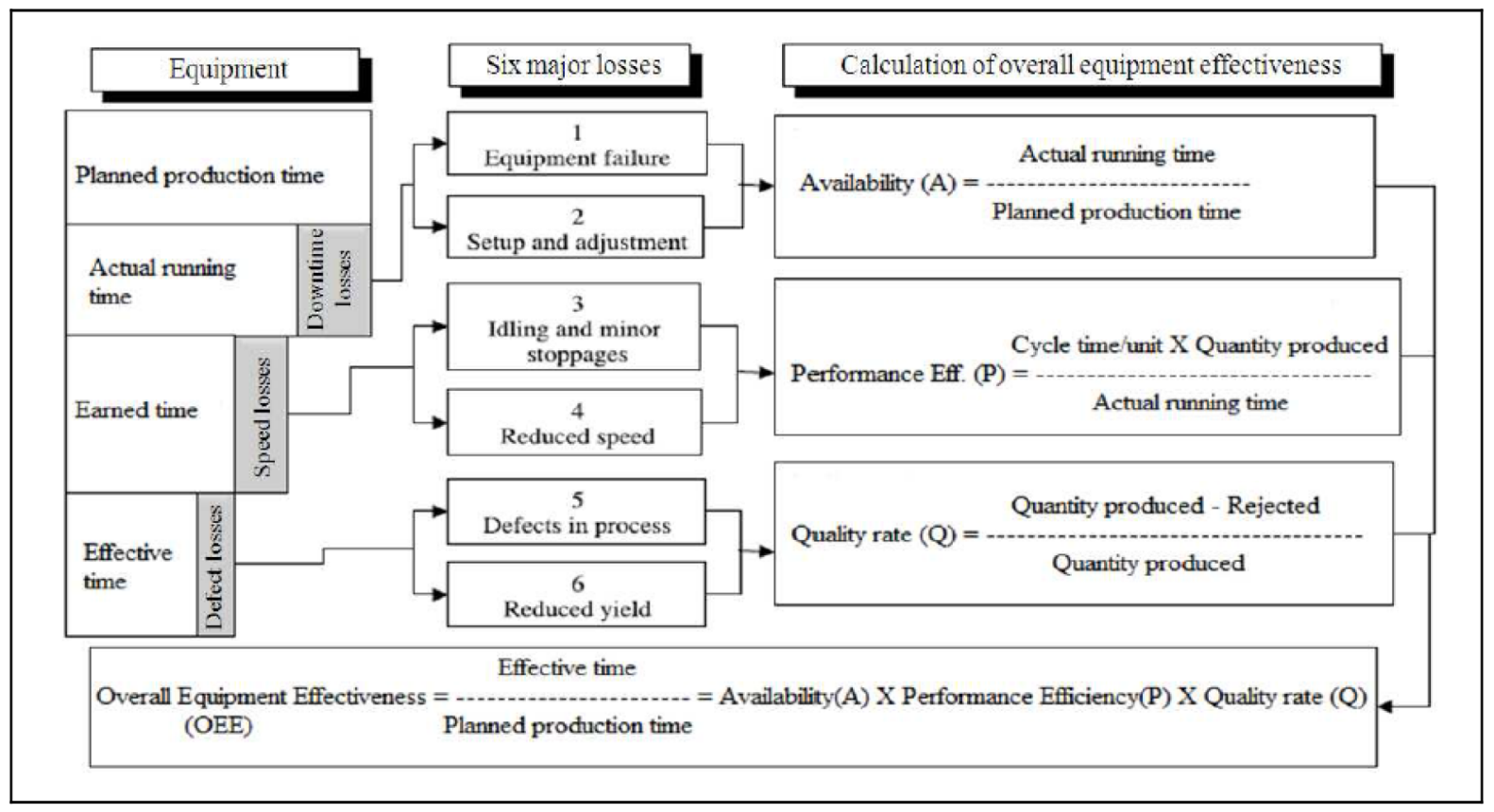

Figure 1. Six big losses and calculation of OEE (Eswaramurthi \& Mohanram, 2013)

Performance measurement is important in management since it identifies the gap between current performance and the desired performance and also provides indication of progress towards closing the gaps (Samad et al., 2012). Formulation of OEE is suggested to be implemented in systematic way which starts from the analytical definition 
of OEE (Cesarotti, Giuiusa \& Introna, 2013). Time-based performance (Dröge, Jayaram \& Vickery, 2004; Iyer, Germain \& Frankwick, 2004) and more customer-related metrics (Ali \& Deif, 2016) should be included to evaluate the customer delivery performance. Time effectiveness, delivery or transport related processes, inventory and resources are among the quantitative performance metrics required for the assessment of Leanness (Pakdil \& Leonard, 2014; Roser et al., 2014)

On top of that, Overall Equipment Effectiveness-Market based (OEE-MB) as introduced by Anvari, Edwards and Starr (2010) provides a tool not only for monitoring but also for managing improvement by taking into consideration all losses within market time for meeting both internal and external demands. Besides, effect of demand uncertainties on the supplier, internal and customer integration (Morash \& Clinton, 1998; Rosenzweig, Roth \& Dean, 2003; Boon-itt \& Yew-Wong, 2011) as well as the flexibility of production, full utilization of men and machines, and also the coordination between men and machines (Mugwindiri et. al., 2013) are studied. Feasible plan on strategic level and also tactical level should maintain the desired production rate which in favors of manufacturing settings and demand environment by forecasting volume in the future (Gyulai \& Monostori, 2017; Ali \& Deif, 2016). It can be said that existing OEE is not sufficient to assess the losses associated with manufacturing resources with separate metrics (Eswaramurthi \& Mohanram, 2013).

\subsection{Modifications of Overall Equipment Effectiveness (OEE)}

Companies should be equipped with integrated and balanced performance measure to have a better performance and availability of the production facilities (Kennerley \& Neely, 2003; Fleischer, Weismann \& Niggeschmidt, 2006). The inputs of the production process such as man, machine, material and methods and the way to identify and eliminate the losses associated with each for outputs maximization is the key of improvement (Eswaramurthi \& Mohanram, 2013).

A measure to reflect the level of customer demand is filled on time by measuring the ratio of target delivery delay over the delivery delay has been proposed by Ali and Deif (2016). The novel integrated metric combines Overall Work-In-Progress Efficiency (OWE), OEE and Overall Service Level (OSL) in accessing Leanness level of company. They are to measure the responsiveness to market and WIP level to reduce lean waste from all aspects.

In addition, the losses exist within market time of satisfying the needs of internal and external markets have been considered (Anvari et al., 2010). The time losses before the loading time or within the market time is not classified as losses until the operation time of machine could not meet the market demand from either internal or external. The concept of the Overall Equipment Effectiveness-Market based (OEE-MB) is illustrated as in Figure 2 below:

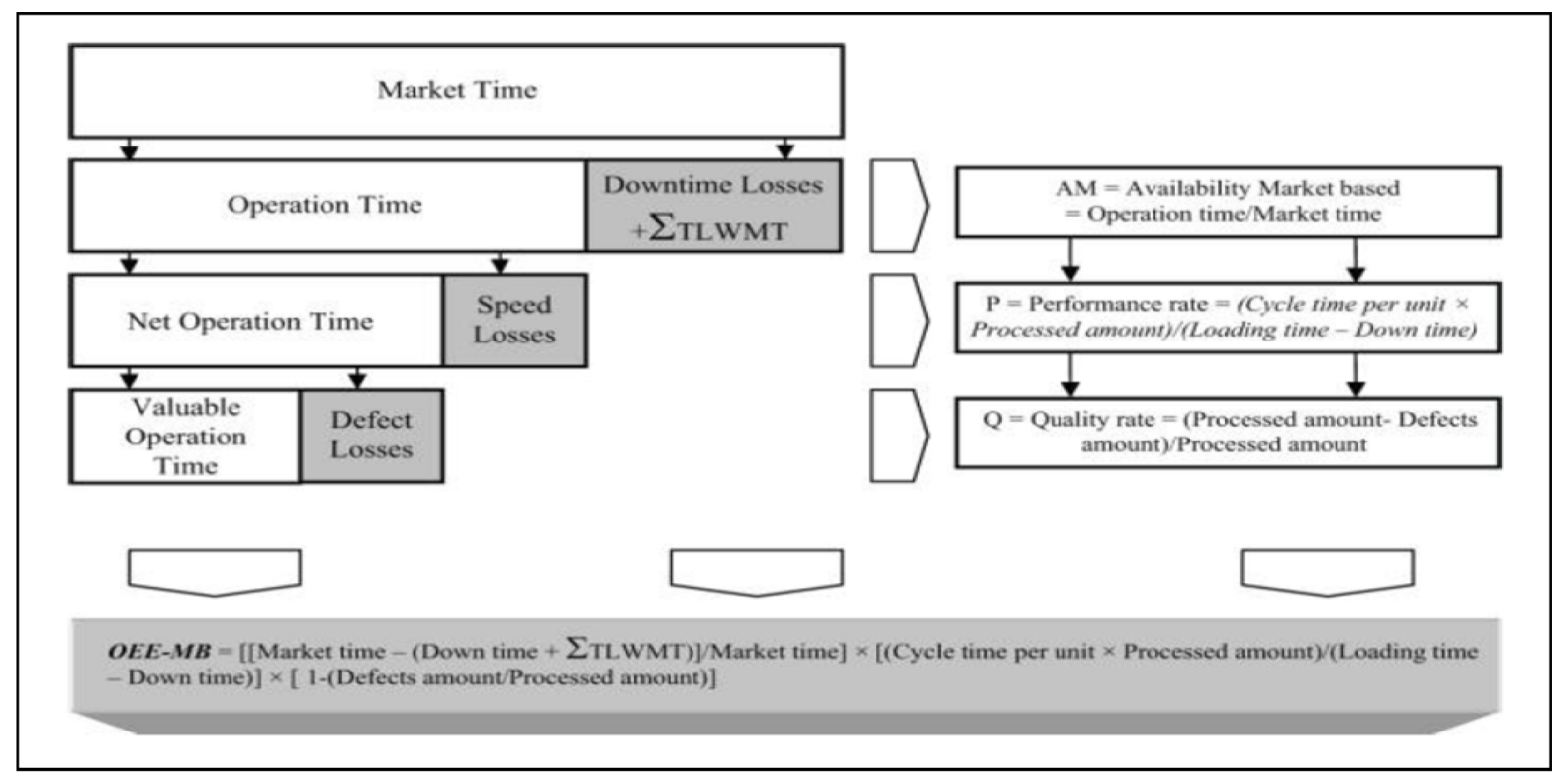

Figure 2. The concept of OEE-MB and the relationship between elements (Anvari et al., 2010) 
This is a useful concept because the OEE-MB will change accordingly with the fluctuation of demand and hence promoting management to look into any existence of time loss before the loading time especially when the production is not able to meet market need. Examples of the time loss before loading time include time spent on any disruption to the production schedule, time spent on carrying out current orders, shortage of labor due to daily shop floor meetings, and training, as well as all non-operational time due to lack of material, electricity and utilities such as water (Anvari et al., 2010).

On the other hand, synchronization between inputs and operational factors of production system, are promoted by the measure called Overall Throughput Effectiveness, OTE or System OEE which are similar to the concept of OEE at factory level. (Huang, Dismukes, Shi, Su, Razzak, Bodhale \& Robinson, 2003; Oechsner, Pfeffer, Pfitzner, Binder, Müller \& Vonderstrass, 2002; Razzak, Daley \& Dismukes, 2002). Other evaluation of resources such as man power has also been presented by Chen and Sarker (2015) and it shows that employee training, combination of individual and organizational learning, continuous improvement as well as reduction of forgetting effect are keys to reduce production cost and improve flexibility of production planning. Besides, Overall Resource Effectiveness (ORE) addresses various kind of losses in manufacturing system (Eswaramurthi \& Mohanram, 2013). Losses include the breakdown of facility, shortage of material and absence of man power are quantified to help decision makers to further analyze and continually improve the performance of resources accordingly.

Last but not least, transformation of position from one station to another, of which its service vehicles affect and are affected by the equipment losses or losses propagation from other processes (Cesarotti et al., 2013). Overall Vehicle Effectiveness (OVE) and also Transportation Overall Vehicle Effectiveness (TOVE) have been introduced to measure the vehicle performance and operating availability (Simons, Mason, \& Gardner, 2004; Villarreal, 2012). In order to effectively track out wastes which contribute to losses in the TOVE, it is recommended to elaborate the operation using Transportation Value Stream Mapping (TVSM). The map enables explanation of the operation and the identification of all relevant wastes along with its causes (Villarreal, Sañudo, Vega, Macias \& Garza, 2012; Villarreal, 2012).

In short, internal integration breaks down functional barriers and engenders cooperation, which forms the basis for the coordination of information flow across functions (Flynn, Huo \& Zhao, 2010). Besides, the satisfaction of multiple clients or fulfillment of customer demand, inventory level as well as variable processing time are some process parameters to be deliberately handled to retain production objectives and promote synchronization between workstations (Graves, 1981).

\section{Methodology}

As the subject of study, a production line which consists of five manufacturing processes within an aerospace partmanufacturing company is studied and time data is collected from it. The illustration of the processes is shown in Figure 3 below.

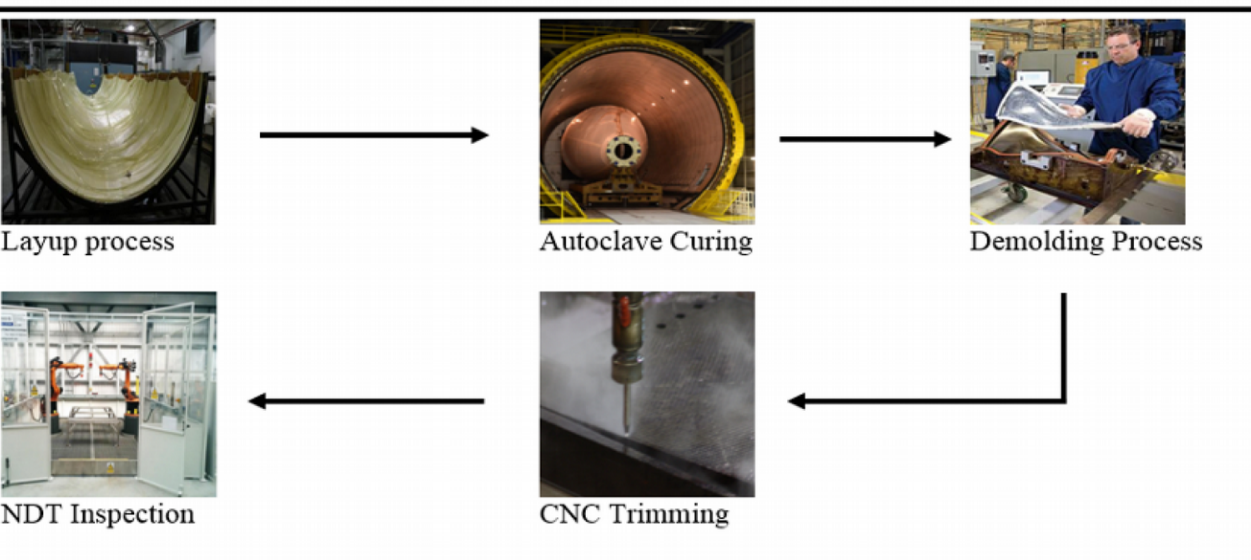

Figure 3. Process flow of aerospace part-manufacturing company 
In short, first process being the layup process would stack ply materials, layer by layer manually, which will be cured and hardened in second process namely autoclave curing process by mean of autoclave. It is followed by separating the harden ply materials or composite part from its mold in demold process. They are transferred into suitable trimming mold before their excessive portion of composites is trimmed in CNC process. Last process is the Non Destructive Testing (NDT) section where inspection is carried out to ensure that there is no void and crack within the product.

Cycle time and other process parameters are collected so that they are used to construct simulation model for experimentation and analysis purpose. Number of operators, level of inventory and operational factors as shown in following Table 1 are collected.

Construction of simulation model from the data collected is for the experimentation purpose. Simulation method is extensively used by industry to test different scenarios, model any abnormal situation and drive recommendation based on the results once the desired target is attained in the model (De Carlo, Arleo \& Tucci, 2014; Zhou, Zhao, Li, Zhou, Zhang \& Shang, 2009). Simulation-based framework has also been used to model the market behavior and production system so that demand and execution uncertainty could be considered as well as for the identification of production waste such as waiting, work in progress, inventories and transportation (Badiger \& Gandhinathan, 2008; Heilala, Vatanen, Tonteri, Montonen, Lind, Johansson et al., 2008; Ponsignon \& Mönch, 2014). The conceptual model to represent the production line of company is shown below:

\begin{tabular}{|c|c|c|c|c|}
\hline & \multicolumn{4}{|c|}{ Unit of Key Performance Indexes and Measures } \\
\hline & & Time Unit & & Resources Unit \\
\hline Supplier Process & & $\begin{array}{l}\text { Cycle time } \\
\text { Waiting time in queue } \\
\text { Production duration } \\
\text { Takt time }\end{array}$ & & $\begin{array}{l}\text { Number of Operator } \\
\text { Amount of product completed } \\
\text { Deviation between production and demand }\end{array}$ \\
\hline Transportation & & $\begin{array}{l}\text { Waiting duration for forklift } \\
\text { Idle time of forklift } \\
\text { Transportation time }\end{array}$ & & $\begin{array}{l}\text { Utilization rate of the forklift per transportation } \\
\text { Availability of forklift. } \\
\text { Number of forklift } \\
\text { Size or capacity of forklift }\end{array}$ \\
\hline Customer Process & & $\begin{array}{l}\text { Waiting time for availability of resource } \\
\text { Takt Time } \\
\text { Cycle time } \\
\text { Duration of production }\end{array}$ & & $\begin{array}{l}\text { Number of operator available } \\
\text { Ratio of unit transported to amount of buffer } \\
\text { Length of queue. } \\
\text { Deviation between production and customer } \\
\text { demand }\end{array}$ \\
\hline
\end{tabular}

Table 1. Measures and Key Performance Index (KPIs) for analysis of interruption

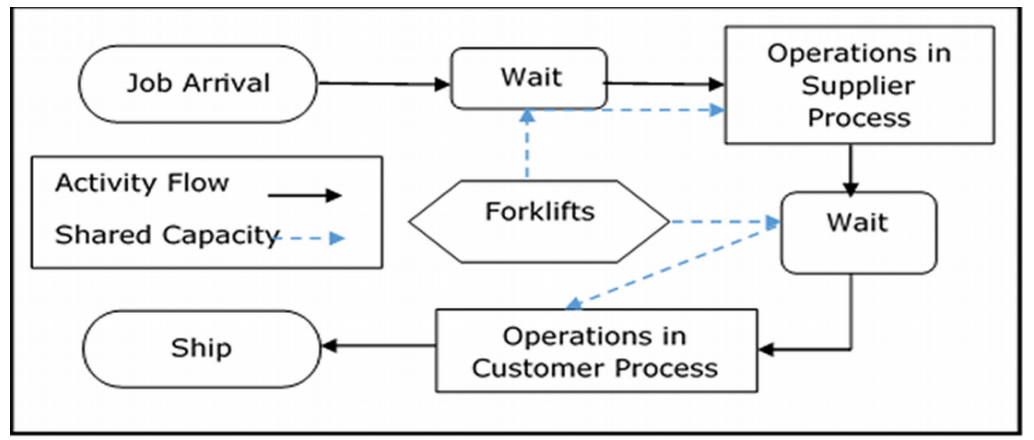

Figure 4. Conceptual model of production system in the study

Both of the supplier and customer processes in Figure 4 are pairs of any two consecutive processes and could be automated or manual process which are seized by the jobs. After certain period of time unit (cycle time of each process), jobs will move on to next pair of supplier-customer process. Besides, there are transporting activities 
carried out between the processes to facilitate the movement of materials. Two separate experiments are carried out on the constructed model as described in following sections.

\subsection{Experiment 1: Impact of Internal Transportation Efficiency on Processes}

Experiment 1 aims to study the efficiency of the internal transportation process which is performed by mean of five shared forklifts as in Figure 4 above. In addition to the cycle time as per actual scenario, the transportation between processes is also simulated at different efficiency as shown in following Table 2.

\begin{tabular}{|c|c|c|c|c|c|}
\hline \multirow[b]{2}{*}{ Scenario } & \multirow[b]{2}{*}{ Unit Available } & \multirow[b]{2}{*}{ Capacity Type } & \multicolumn{3}{|c|}{ Cycle Time (Hour) } \\
\hline & & & Min & Mod & Max \\
\hline Actual Cycle Time (CT) & 5 & Forklift & 0.75 & 1.25 & 2 \\
\hline Half Cycle Time (CT) & 5 & Forklift & 0.37 & 0.65 & 1 \\
\hline $25 \%$ Cycle Time (CT) & 5 & Forklift & 0.19 & 0.31 & 0.5 \\
\hline
\end{tabular}

Table 2. Cycle Time of Transportation Process under Different Efficiency of Transportation

Shorter cycle time of transportation in Table 2 represents better efficiency. Half cycle time represents the cycle time of transporting activities has been reduced until $50 \%$ of its actual cycle time. Same goes to the $25 \%$ cycle time scenario. Note should be taken that the cycle time of other workstations remain the same as in the actual production system for all of these 3 scenarios. The lead time and throughput of each workstation under these 3 scenarios of transportation efficiency are collected and will be discussed in section 4 .

\subsection{Experiment 2: Examination of Imbalanced Capacity between Workstations}

Gan and Chong (2014) had selected two bottleneck candidates with highest utilization and longest wait time in buffer. The study states that bottleneck process is at upstream when a process is starved or waiting for part whereas blocking phenome

From the site observation, it has been found that capacity is not synchronized throughout the production system. Idle resources and tight capacity could be sighted in different workstations except NDT workstation. NDT limits the production rate of the entire product system at 27 sets of products in every month even though most of other workstations have excessive capacity.

Experiment 2 measures the difference of throughput rate could be afforded by each workstation. In actual, the production rate of the company is scheduled to be one set per day with 24 hours of inter-arrival time. However, the inter-arrival time in experiment 2 is halved to be 12 hours per set to represent faster and higher demand. This is to prevent the situation where throughput rate is constrained by the slow arrival of material to truly quantify the maximum throughput of each workstation. The experimental factor in experiment 2 includes the difference in cycle time of each workstation in each of five scenarios. The experimental design is as shown in Table 3.

\begin{tabular}{|l|c|c|c|c|c|}
\hline \multirow{2}{*}{\multicolumn{1}{c|}{ Process }} & Scenario 1 & Scenario 2 & Scenario 3 & Scenario 4 & Scenario 5 \\
\cline { 2 - 6 } & Actual & 0 & 0 & 0 & 0 \\
\hline Autoclave & 0 & Actual & 0 & 0 & 0 \\
\hline Demold & 0 & 0 & Actual & 0 & 0 \\
\hline CNC & 0 & 0 & 0 & Actual & 0 \\
\hline NDT & 0 & 0 & 0 & 0 & Actual \\
\hline
\end{tabular}

Table 3. Variation in cycle time as the experimental factor in determining difference in throughput of each process 
In short, the cycle time of Layup process in Scenario 1 remains the same as in the actual condition whereas other workstations have zero cycle time in scenario 1 . This is to make sure that other workstation would not delay the material flow throughout the production system. In other words, the output of the production system is solely based on the capacity of layup process in scenario 1 . Similar setting is repeated in scenario 2, 3, 4 and 5 by fixing the cycle time of autoclave, demold, CNC and NDT as per actual condition in scenario 2, 3, 4, and 5 respectively. The amount of throughput at each workstation is summarized and discussed in section 4 .

\section{Results and Discussion}

Transportation efficiency and its impact onto manufacturing process are the subject of study in experiment 1 whereas the imbalanced capacity is the focal point of experiment 2. In short, Experiment 1 has shown that the lead time and output of each workstation are affected by the transporting activities which are carried out between processes. On the other hand, the capacity available and maximum output could be afforded in each workstation have been proven to be imbalanced in Experiment 2. Therefore, proper measures are proposed in this section to quantify these findings to monitor the situation.

\subsection{Availability and Performance Ratio of Transportation Process}

In experiment 1, the impact of transportation efficiency on workstations is quantified in term of total value added time elapsed in each workstation and amount of output has been processed by each of them. They are shown in following Table 4.

Both the lead time and VA time in Table 4 reduce whenever the transportation efficiency improves and the trend reverses in the scenario of $25 \%$ CT. Efficient transportation within the production system enable less throughput requirement for continuous material flow until the extent where more incoming materials are transferred from workstation to another at higher flow rate to prevent idle capacity. This is supported by the trend of throughput in Table 4.

In addition, longest lead time is sighted in the scenario with shorter transportation cycle time because the wait time per entity has increased due to increased amount of throughput in each workstation under that scenario. This signifies that the transporting activities within production system should be monitored and measured because it would affect the delivery performance of the production system.

In short, results from Experiment 1 shows that efficiency of transporting activities contributes to delay delivery of products. Appropriate measure for internal transportation should be proposed to improve the throughput and lead time of WIP throughout the production system. This is not implemented by the company at current stage because it focuses on manufacturing processes only via OEE. Therefore, similar concept as the OEE and OPE has been applied onto the transportation process to ensure collaboration of processes. The availability ratio for the transporting activities, $A_{T}$ in the case company is proposed as in Formula 1.

\begin{tabular}{|c|c|c|c|c|c|c|c|c|c|}
\hline \multirow[b]{2}{*}{ Process } & \multicolumn{3}{|c|}{ Lead Time (Hour) } & \multicolumn{3}{|c|}{ VA Time (Hour) } & \multicolumn{3}{|c|}{ Output (Set) } \\
\hline & $\begin{array}{l}\text { Actual } \\
\text { CT }\end{array}$ & $\begin{array}{l}\text { Half } \\
\text { CT }\end{array}$ & $25 \%$ CT & $\begin{array}{l}\text { Actual } \\
\text { CT }\end{array}$ & $\begin{array}{l}\text { Half } \\
\text { CT }\end{array}$ & $25 \% \mathrm{CT}$ & $\begin{array}{l}\text { Actual } \\
\text { CT }\end{array}$ & $\begin{array}{l}\text { Half } \\
\text { CT }\end{array}$ & $25 \%$ CT \\
\hline Layup & 28.96 & 27.63 & 28.11 & 15.99 & 15.97 & 15.97 & 58.4 & 58.25 & 59.18 \\
\hline Autoclave & 21.76 & 21.51 & 21.23 & 16.87 & 17.02 & 17.03 & 56.48 & 56.13 & 57.10 \\
\hline Demold & 1.00 & 1.01 & 1.02 & 0.99 & 0.99 & 0.99 & 56.15 & 55.88 & 57.03 \\
\hline $\mathrm{CNC}$ & 30.13 & 28.56 & 28.1 & 19.68 & 19.67 & 19.66 & 53.18 & 52.93 & 54.25 \\
\hline NDT & 167.4 & 164.4 & 176.4 & 24.03 & 23.97 & 24.04 & 26.95 & 27.23 & 27.3 \\
\hline Total & 249.3 & 243.1 & 254.9 & 77.56 & 77.62 & 77.69 & - & - & - \\
\hline
\end{tabular}

Table 4. Total Lead Time and Output of Processes under Different Transportation Efficiency 
Unnecessary transportation is discouraged in formula 1 by prioritizing the transportation process based on the queue length at the destination process. Besides, the amount of output transported should be close to the input to promote rapid turnover of products or WIP through forklift. Amount of WIP stays inside the service vehicle has to be kept minimal to ensure readiness of shared forklift of following batch of transportation. Besides, equipment utilization of forklift is included into the proposed performance ratio of transportation as shown in Formula 2 and the computation of transportation is shown in Table 5:

$$
\mathrm{P}_{\mathrm{T}}=\text { Total Transportation Uptime/Total Service Duration of Forklift } \cdot \text { Utilization of Forklift }
$$

The utilization of the forklift is considered to prevent excessive investment in the service vehicle and to measure the frequency of it is needed. It can be said that there are excessive capacity in the forklift for the scenario with $25 \%$ of cycle time because the performance of forklift could carter the transportation requirement with less capacity. Moreover, performance ratio also focuses on the quality service of the transportation which is progressing towards its destination. It excludes those wait during along the service duration. $25 \%$ cycle time represents the scenario with highest portion of quality service with shortest transporting time.

Transportation Measure, TM as shown in Formula 3, is then calculated and tabulated in Table 6 for comparison purpose:

$$
\text { Transportation Measure }=\text { Availability Ratio, } \mathrm{A}_{\mathrm{T}} \cdot \text { Performance Ratio, } \mathrm{P}_{\mathrm{T}}
$$

\begin{tabular}{|c|c|c|c|c|c|c|c|c|c|}
\hline \multirow[b]{2}{*}{ Destination } & \multicolumn{3}{|c|}{$\begin{array}{l}\text { Forklift Utilization } \\
\qquad(\%)\end{array}$} & \multicolumn{3}{|c|}{$\begin{array}{l}\text { Total Service Duration } \\
\text { (Hour) }\end{array}$} & \multicolumn{3}{|c|}{$\begin{array}{l}\text { Uptime/ Total Service Duration } \\
\qquad(\%)\end{array}$} \\
\hline & $\begin{array}{c}\text { Actual } \\
\text { cycle } \\
\text { time }\end{array}$ & $\begin{array}{l}\text { Half } \\
\text { cycle } \\
\text { time }\end{array}$ & $\begin{array}{l}25 \% \\
\text { cycle } \\
\text { time }\end{array}$ & $\begin{array}{l}\text { Actual } \\
\text { cycle } \\
\text { time }\end{array}$ & $\begin{array}{l}\text { Half } \\
\text { cycle } \\
\text { time }\end{array}$ & $\begin{array}{l}25 \% \\
\text { cycle } \\
\text { time }\end{array}$ & $\begin{array}{c}\text { Actual } \\
\text { cycle } \\
\text { time }\end{array}$ & $\begin{array}{l}\text { Half } \\
\text { cycle } \\
\text { time }\end{array}$ & $\begin{array}{l}25 \% \\
\text { cycle } \\
\text { time }\end{array}$ \\
\hline Layup & \multirow{5}{*}{37.50} & \multirow{5}{*}{18.66} & \multirow{5}{*}{9.42} & 2.11 & 0.85 & 0.37 & 63.98 & 80.00 & 89.19 \\
\hline Autoclave & & & & 1.86 & 0.78 & 0.35 & 72.58 & 87.18 & 94.29 \\
\hline Demold & & & & 2.04 & 0.78 & 0.35 & 65.69 & 85.90 & 94.29 \\
\hline $\mathrm{CNC}$ & & & & 1.89 & 0.78 & 0.35 & 71.43 & 87.18 & 94.29 \\
\hline NDT & & & & 1.87 & 0.76 & 0.35 & 71.66 & 88.16 & 94.29 \\
\hline
\end{tabular}

\begin{tabular}{|c|c|c|c|c|c|c|c|c|c|}
\hline \multirow[b]{2}{*}{$\begin{array}{l}\text { Transportation } \\
\text { Destination }\end{array}$} & \multicolumn{3}{|c|}{ Actual transport CT } & \multicolumn{3}{|c|}{ Half transport CT } & \multicolumn{3}{|c|}{$25 \%$ transport $\mathrm{CT}$} \\
\hline & $\begin{array}{c}\mathrm{A}_{\mathrm{T}} \\
(\%)\end{array}$ & $\begin{array}{l}\mathrm{P}_{\mathrm{T}} \\
(\%)\end{array}$ & $\begin{array}{l}\text { TM } \\
(\%)\end{array}$ & $\begin{array}{c}\mathbf{A}_{\mathrm{T}} \\
(\%)\end{array}$ & $\begin{array}{l}\mathrm{P}_{\mathrm{T}} \\
(\%)\end{array}$ & $\begin{array}{l}\text { TM } \\
(\%)\end{array}$ & $\begin{array}{l}\mathrm{A}_{\mathrm{T}} \\
(\%)\end{array}$ & $\begin{array}{l}\mathrm{P}_{\mathrm{T}} \\
(\%)\end{array}$ & $\begin{array}{l}\text { TM } \\
(\%)\end{array}$ \\
\hline Layup & 7.69 & 23.99 & 1.85 & 8.57 & 14.93 & 1.28 & 8.23 & 8.40 & 0.69 \\
\hline Autoclave & 20.38 & 27.22 & 5.55 & 22.25 & 16.27 & 3.62 & 23.78 & 8.88 & 2.11 \\
\hline Demold & 99.64 & 24.63 & 24.54 & 100.0 & 16.03 & 16.03 & 100.0 & 8.88 & 8.88 \\
\hline $\mathrm{CNC}$ & 9.55 & 26.79 & 2.56 & 11.24 & 16.27 & 1.83 & 11.85 & 8.88 & 1.05 \\
\hline NDT & 0.70 & 26.87 & 0.19 & 0.71 & 16.45 & 0.12 & 0.66 & 8.88 & 0.06 \\
\hline
\end{tabular}

Table 5. Forklift utilization, total duration of transportation per product to all workstations, and uptime ratio in Experiment 1

Table 6. Availability, performance ratio and transportation measure of case company in Experiment 1

Transportation measures reduce along with the shorter cycle time of transporting activities because of reduced forklift utilization as in Table 5. Transportation measure considers both utilization and efficiency of forklift. 
Moreover, queue length at the destination process help to prioritize the assignment of shared forklifts to one workstation over the other. NDT workstation, for instances, has the lowest priority among all because it has lengthy queue due to its tight utilization.

The proposed TM is useful to pin point any individual process which contributes to delayed delivery. In short, formula 1 through 3 establishes balance between utilization, excessive capacity of forklift and also the efficient assignment of forklift to the workstations according to its urgency. It encourages less work or job in transportation process based on the necessity of transportation.

\subsection{Availability and Performance Ratio of Manufacturing Process}

Results of experiment 2 is measured in term of throughput of workstations in the company when each of them is not restricted by the cycle time or performance of another workstation they connect with. The throughput is summarized as in Table 7.

\begin{tabular}{|l|r|r|r|r|r|}
\hline \multirow{2}{*}{\multicolumn{1}{|c|}{ Process }} & \multicolumn{5}{|c|}{ Throughput (Set) } \\
\cline { 2 - 6 } & Scenario 1 & Scenario 2 & Scenario 3 & Scenario 4 & \multicolumn{1}{c|}{ Scenario 5 } \\
\hline Layup & $\mathbf{8 7 . 6 5}$ & 121.45 & 124.80 & 121.75 & 121.45 \\
\hline Autoclave & 87.43 & $\mathbf{8 2 . 4 5}$ & 116.40 & 118.65 & 117.58 \\
\hline Demold & 87.13 & 82.00 & $\mathbf{1 0 9 . 0 0}$ & 116.08 & 113.93 \\
\hline CNC & 86.95 & 81.65 & 102.13 & $\mathbf{7 1 . 0 0}$ & 110.05 \\
\hline NDT & 86.80 & 81.28 & 94.35 & 69.40 & $\mathbf{2 8 . 1 8}$ \\
\hline
\end{tabular}

Table 7. Throughput at each process after the arrival rate is doubled

The shaded values in Table 7 is the throughput could be supported by corresponding workstation where arrival rate of incoming material is doubled and all the other interconnecting workstations are having zero cycle time. In other words, layup process of the case company could only support 87.65 sets as in Scenario 1. From the results in scenario 2 through scenario 5, throughput could be supported by autoclave, demold, CNC and NDT is 82, 109, 71 and 28 sets respectively.

This shows that the throughput rate of the case company is currently restricted by NDT workstation whereas the excessive capacity in the production system could be as high as 80 sets in demold station. This has proven that high throughput rate in supplier processes are restricted by the unreliable downstream capacity of NDT curing process.

Therefore, the company needs to balance the capacity of the production system. This is supported by Cuatrecasas-Arbós et al. (2015) which states that imbalance between workstation will cause waiting parts in queue especially before the operation with higher processing time. Both of the capacity planning and production planning, therefore, should be planned in accordance to the NDT workstation which is the bottleneck process and has paced the entire production system.

Quantifications of performance of company are necessary to monitor and improve the production system from time to time. Relationship between transporting activities and manufacturing processes which will affect the performance of production system as well as excessive capacity have been proven in Experiment 1 and 2. Therefore, quantifications of workstations, namely operational ratio $\left(\mathrm{OPR}_{\mathrm{cd}}\right)$ and productivity of workstation $\left(P_{p s}\right)$, are proposed to incorporate deviation between output with both customer demand and input as below:

$$
\text { Operational Ratio, } \mathrm{OPR}_{\mathrm{cd}}=\text { No. of Output/ Customer demand }
$$

$$
\text { Operational Ratio, } \mathrm{OPR}_{\mathrm{cd}}=\text { Customer demand/ No. of Output }
$$


Formula $4 \mathrm{a}$ is used whenever the output of production could not fulfil customer demand whereas Formula $4 \mathrm{~b}$ is to measure the loss for the case of overproduction. On the other hand, turnaround of workstation is monitored under Formula 5 so that the amount of WIP stay within the workstation could be kept minimal. Both operational ratio and productivity encourage fulfilment of customer demand using less resources such as materials and capacity of equipment in more efficient way or rapid turnaround rate. Given the fact that customer demand is 29 sets per month as observed and studied in the company, the availability ratio of each workstation, as the multiplication of operational ratio and productivity, is summarized as in Table 8:

$$
\text { Availability }=\mathrm{OPR}_{\mathrm{cd}} \cdot P_{w s}
$$

\begin{tabular}{|c|c|c|c|c|c|c|}
\hline \multirow[b]{2}{*}{ Process } & \multirow[b]{2}{*}{$\begin{array}{l}\text { Customer } \\
\text { demand }\end{array}$} & \multicolumn{2}{|c|}{ Throughput } & \multicolumn{2}{|c|}{ Components of availability ratio } & \multirow[b]{2}{*}{$\begin{array}{c}\text { Availability } \\
\qquad(\%)\end{array}$} \\
\hline & & $\begin{array}{l}\text { Input } \\
\text { (set) }\end{array}$ & $\begin{array}{l}\text { Output } \\
\text { (set) }\end{array}$ & $\begin{array}{l}P_{\mathrm{mc}} \\
(\%)\end{array}$ & $\begin{array}{l}\mathrm{OPR}_{\mathrm{cd}} \\
(\%)\end{array}$ & \\
\hline Layup & 29 & 61.10 & 58.40 & 95.58 & 49.66 & 47.46 \\
\hline Autoclave & 29 & 58.25 & 56.48 & 96.96 & 51.35 & 49.79 \\
\hline Demold & 29 & 56.30 & 56.15 & 99.73 & 51.65 & 51.51 \\
\hline $\mathrm{CNC}$ & 29 & 55.95 & 53.18 & 95.05 & 54.53 & 51.83 \\
\hline NDT & 29 & 53.10 & 26.95 & 50.75 & 92.93 & 47.17 \\
\hline
\end{tabular}

Table 8 . Operational ratio and productivity of proposed availability ratio

From the data in Table 8, NDT workstation posts the lowest value of productivity because the deviation between input and output is the largest among all and this signifies tight capacity. On the other hand, operational ratio of other workstations stand at 50\% because there are overproduction issues due to more outputs than the required amount. Again, this is aligned with the results of Experiment 2 which suggest that there is lack of synchronized capacity between workstations.

From the observation, higher equipment utilization of workstations contributes to higher availability of Overall Equipment Effectiveness (OEE) implemented in the case company. However, higher inventory level especially the NDT workstation with low productivity ratio of $50.75 \%$ highlights that this is the hidden waste could not be quantified by the case company using OEE. This demonstrates the importance of including consideration of customer demand in the availability ratio.

In fact, production leveling is one of the Lean techniques to reduce unevenness and wastes in industry (Chahal \& Narwal, 2017). In order to ensure balanced capacity and same production pace throughout the entire production system of the case company, performance ratio is proposed to incorporate Takt time as in Formula 7. Takt time or the production pace with respect to customer demand as in Formula 8, is like the main heartbeat of the entire production system which all workstations should follow.

$$
\text { Performance ratio }=100 \%-\mid \text { Takt time }- \text { Cycle time } \mid / \text { Takt Time }
$$

Takt Time $=($ Maximum Capacity. Historical Equipment Utilization $) /$

(Demand. Resource Requirement per Production)

Incorporation of Takt time keeps the production rate up to that level which is as close to the demand-fulfilling pace as possible. Any deviation of cycle time of each workstation from the Takt time is either due to inability of fulfilling customer demand or overproduction issue. Both of them are equally critical and need to be quantified to 
prevent Lean wastes. Besides, historical utilization of each workstation makes sure the capacity available for the fulfilment of demand is reliable and attainable. Computation of Takt time based on 29 sets of customer demand is summarized in following Table 9 .

Due to the excessive capacity in demold workstation, its historical equipment utilization which is extremely low has provided lowest Takt time among all to fulfil 29 sets of demand. In other words, if demold workstation elapsed more than 1 hour in fulfilling demand, over-processing or sub-optimal production pace is sighted. In addition, historical equipment utilization provides a reference of capacity available for the production planning because all the capacity commit has been proven to be achievable and practical. Consequently, comparison of cycle time and Takt time is summarized in following Table 10.

\begin{tabular}{|c|c|c|c|c|c|c|c|c|}
\hline \multirow[b]{2}{*}{ Workstation } & \multicolumn{8}{|c|}{ Capacity and Takt Time for 29 sets } \\
\hline & $\begin{array}{l}\text { Process } \\
\text { type }\end{array}$ & Unit & $\begin{array}{c}\text { Working } \\
\text { Hour/ } \\
\text { Day }\end{array}$ & $\begin{array}{l}\text { Working } \\
\text { Day/ } \\
\text { Month }\end{array}$ & $\begin{array}{c}\text { Max. } \\
\text { Capacity } \\
\text { (Hour) }\end{array}$ & $\begin{array}{c}\text { Historical } \\
\text { Utilization } \\
(\%)\end{array}$ & $\begin{array}{l}\text { Unit } \\
\text { Required/ } \\
\text { Operation }\end{array}$ & $\begin{array}{l}\text { Takt } \\
\text { Time } \\
\text { (Hour) }\end{array}$ \\
\hline Layup & Manual & 20 & 16 & 24 & 7680 & 64.86 & 10 & 17.2 \\
\hline Autoclave & Automated & 2 & 24 & 30 & 1440 & 49.62 & 0.75 & 32.9 \\
\hline Demold & Manual & 12 & 16 & 24 & 4608 & 6.48 & 10 & 1.0 \\
\hline $\mathrm{CNC}$ & Automated & 2 & 24 & 30 & 1440 & 72.65 & 1 & 36.1 \\
\hline NDT & Automated & 1 & 24 & 30 & 720 & 67.41 & 0.75 & 22.3 \\
\hline
\end{tabular}

Table 9. Capacity available and Takt time of each workstation

\begin{tabular}{|l|r|r|r|}
\hline Workstation & $\begin{array}{c}\text { Cycle Time per Set } \\
\text { (Hour) }\end{array}$ & $\begin{array}{c}\text { Takt Time } \\
\text { (Hour) }\end{array}$ & $\begin{array}{c}\text { Performance Ratio } \\
\text { (\%) }\end{array}$ \\
\hline Layup & 15.99 & 17.2 & 93.11 \\
\hline Autoclave & 16.87 & 32.9 & 51.35 \\
\hline Demold & 0.99 & 1.0 & 96.84 \\
\hline CNC & 19.68 & 36.1 & 54.53 \\
\hline NDT & 24.03 & 22.3 & 92.39 \\
\hline
\end{tabular}

Table 10. Performance ratio computed from comparison of cycle time and Takt time

Lower performance ratio in Autoclave and $\mathrm{CNC}$ workstation are due to excessive equipment utilization with respect to customer demand. This could be sighted from shorter cycle time than Takt time which signifies overproduction. It is recommended to align output of workstations with output rate of bottleneck or adjust them based on amount of work in queue (Thürer et al., 2017; Yuan \& Graves, 2016). For the case company, all workstations should not produce more than 27 sets because it is the maximum rate could be supported by NDT section. In short, tactical and strategical production planning should be monitored via proposed availability and performance ratio respectively to prevent over-processing and over production at the same time fulfilling customer demand.

\section{Conclusion}

Internal transporting activities within the production system has been proven to have impact on the effectiveness of workstations it connects with. Proposed Transportation Measure, TM promotes rapid turnover and transportation of materials as well as prioritize the assignment of shared forklift based on queue length at the destination workstation. This has led to reduction of the lead time and wait time at the same time minimize the frequency of transportation requirement to ensure material flow within production system.

In addition, the comparison of production amount to demand and Takt time in the quantification of workstation ensures that the entire production system is working under the same pace to prevent overproduction and 
over-processing. The case company has been proven to be lack of synchronization of capacity. It is resolved via incorporation of historical equipment utilization in the Takt time computation and performance ratio.

Last but not least, the study promotes and encourages production with lean way. Shorter lead time and wait time are achieved via quantification of transportation activities. Besides, the production rate is always related to the customer demand to reduce the queue length and WIP level. Indirectly, this reduces the wait time and also equipment utilization in contrast to the implemented OEE which promotes high equipment utilization.

In short, effectiveness from the perspective of equipment and material could be considered at the same time without compromising any one of them. Relations between equipment utilization and customer demand has been analyzed and tradeoff between them with inventory level is resolved via the introduction of both availability and performance ratio. New guidance and measure in improving the production system from both tactical production planning and strategical capacity planning are proposed to reduce inventory level and excessive capacity.

\section{Declaration of Conflicting Interests}

The authors declared no potential conflicts of interest with respect to the research, authorship, and/or publication of this article.

\section{Funding}

The authors received financial support from TRGS research grant: TRGS/1/2016/FKP-AMC/01/D00005 for the research, authorship, and/or publication of this article.

\section{References}

Adanna, I.W., \& Shantharam, A. (2013). Improvement of setup time and production output with the use of single minute exchange of die principles (SMED). International Journal of Engineering Research, 2(4), 274-277.

Afefy, I.H. (2013). Implementation of total productive maintenance and overall equipment effectiveness evaluation. International Journal of Mechanical \& Mechatronics Engineering, 13(01), 69-75.

Ali, R., \& Deif, A. (2016). Assessing leanness level with demand dynamics in a multi-stage production system. Journal of Manufacturing Technology Management, 27(5), 614-639.https://doi.org/10.1108/JMTM-08-2015-0064

Anvari, F., Edwards, R., \& Starr, A. (2010). Evaluation of overall equipment effectiveness based on market. Journal of Quality in Maintenance Engineering, 16(3), 256-270. https://doi.org/10.1108/13552511011072907

Badiger, A.S., \& Gandhinathan, R. (2008). A proposal: evaluation of OEE and impact of six big losses on equipment earning capacity. International Journal of Process Management and Benchmarking, 2(3), 234-248. https://doi.org/10.1504/IJPMB.2008.017962

Bamber, C.J., Castka, P., Sharp, J.M., \& Motara, Y. (2003). Cross-functional team working for overall equipment effectiveness (OEE). Journal of Quality in Maintenance Engineering, 9(3), 223-238.

https://doi.org/10.1108/13552510310493684

Baykasoğlu, A., \& Özbakır, L. (2008). Analysing the effect of flexibility on manufacturing systems performance. Journal of Manufacturing Technology Management, 19(2), 172-193. https://doi.org/10.1108/17410380810847909

Benjamin, S.J., Marathamuthu, M.S., \& Murugaiah, U. (2015). The use of 5-WHYs technique to eliminate OEE's speed loss in a manufacturing firm. Journal of Quality in Maintenance Engineering, 21(4), 419-435.

https://doi.org/10.1108/JQME-09-2013-0062

Benttaleb, M., Hnaien, F., \& Yalaoui, F. (2016). Two-machine job shop problem for makespan minimization under availability constraint. IFAC-PapersOnLine, 49(28), 132-137. https://doi.org/10.1016/j.ifacol.2016.11.023

Boon-itt, S., \& Yew-Wong, C. (2011). The moderating effects of technological and demand uncertainties on the relationship between supply chain integration and customer delivery performance. International Journal of Physical Distribution \& Logistics Management, 41(3), 253-276. https://doi.org/10.1108/09600031111123787 
Cesarotti, V., Giuiusa, A., \& Introna, V. (2013). Using Overall Equipment Effectiveness for Manufacturing System Design. INTECH Open Access Publisher. https://doi.org/10.5772/56089

Chahal, V., \& Narwal, M. (2017). An empirical review of lean manufacturing and their strategies. Management Science Letters, 7(7), 321-336. https://doi.org/10.5267/j.msl.2017.4.004

Chen, Z., \& Sarker, B.R. (2015). Aggregate production planning with learning effect and uncertain demand: A case based study. Journal of Modelling in Management, 10(3), 296-324. https:/ doi.org/10.1108/JM2-12-2012-0044

Chiarini, A. (2013). Waste savings in patient transportation inside large hospitals using lean thinking tools and logistic solutions. Leadership in Health Services, 26(4), 356-367. https://doi.org/10.1108/LHS-05-2012-0013

Chong, K.E., Ng, K.C., \& Goh, G.G.G. (2015). Improving Overall Equipment Effectiveness (OEE) through integration of Maintenance Failure Mode and Effect Analysis (maintenance-FMEA) in a semiconductor manufacturer: A case study. In Industrial Engineering and Engineering Management (IEEM), 2015 IEEE International Conference on (1427-1431). IEEE. https:// doi.org/10.1109/IEEM.2015.7385883

Colares, E.M.T. (n.d.). How to solve the trade-off between capacity utilization and service level.

Cuatrecasas-Arbós, L., Fortuny-Santos, J., Ruiz-de-Arbulo-López, P., \& Vintró-Sanchez, C. (2015). Monitoring processes through inventory and manufacturing lead time. Industrial Management \& Data Systems, 115(5), 951-970. https://doi.org/10.1108/IMDS-12-2014-0375

Dal, B., Tugwell, P., \& Greatbanks, R. (2000). Overall equipment effectiveness as a measure of operational improvement-A practical analysis. International Journal of Operations \& Production Management, 20(12), 1488-1502. https://doi.org/10.1108/01443570010355750

De Carlo, F., Arleo, M.A., \& Tucci, M. (2014). OEE Evaluation of a Paced Assembly Line Through Different Calculation and Simulation Methods: A Case Study in the Pharmaceutical Environment. International Journal of Engineering Business Management, 6. https://doi.org/10.5772/59158

Dröge, C., Jayaram, J., \& Vickery, S.K. (2004). The effects of internal versus external integration practices on time-based performance and overall firm performance. Journal of operations management, 22(6), 557-573. https://doi.org/10.1016/j.jom.2004.08.001

Eswaramurthi, K.G., \& Mohanram, P.V. (2013). Improvement of manufacturing performance measurement system and evaluation of overall resource effectiveness. American Journal of Applied Sciences, 10(2), 131. https://doi.org/10.3844/ajassp.2013.131.138

Fawcett, S.E., Calantone, R., \& Smith, S.R. (1997). Delivery capability and firm performance in international operations. International Journal of Production Economics, 51(3), 191-204. https:/ / doi.org/10.1016/S0925-5273(97)000510

Fleischer, J., Weismann, U., \& Niggeschmidt, S. (2006). Calculation and optimisation model for costs and effects of availability relevant service elements. Proceedings of LCE, 675-680.

Flynn, B.B., Huo, B., \& Zhao, X. (2010). The impact of supply chain integration on performance: A contingency and configuration approach. Journal of operations management, 28(1), 58-71. https://doi.org/10.1016/j.jom.2009.06.001

Gan, S.Y., \& Chong, K.E. (2014). Improving throughput and completion date estimation in high precision component manufacturer using simulation approach. Journal of Advanced Manufacturing Technology (JAMT), 7(1).

Gansterer, M., Almeder, C., \& Hartl, R.F. (2014). Simulation-based optimization methods for setting production planning parameters. International Journal of Production Economics, 151, 206-213. https://doi.org/10.1016/j.ijpe.2013.10.016

Graves, S.C., (1981). A review of production scheduling. Operations research, 29(4), 646-675. https://doi.org/10.1287/opre.29.4.646

Gyulai, D., \& Monostori, L., (2017). Capacity management of modular assembly systems. Journal of Manufacturing Systems, 43, 88-99. https://doi.org/10.1016/j.jmsy.2017.02.008 
Heilala, J., Vatanen, S., Tonteri, H., Montonen, J., Lind, S., Johansson, B. et al. (2008). Simulation-based sustainable manufacturing system design. In 2008 Winter Simulation Conference (1922-1930). IEEE.

https://doi.org/10.1109/WSC.2008.4736284

Helo, P.T. (2000). Dynamic modelling of surge effect and capacity limitation in supply chains. International Journal of Production Research, 38(17), 4521-4533. https://doi.org/10.1080/00207540050205271

Huang, R.H., Yang, C.L., \& Cheng, W.C. (2013). Flexible job shop scheduling with due window- a two-pheromone ant colony approach. International Journal of Production Economics, 141(2), 685-697.

https://doi.org/10.1016/j.ijpe.2012.10.011

Huang, S.H., Dismukes, J.P., Shi, J., Su, Q.I., Razzak, M.A., Bodhale, R., \& Robinson, D.E. (2003). Manufacturing productivity improvement using effectiveness metrics and simulation analysis. International Journal of Production Research, 41(3), 513-527. https://doi.org/10.1080/0020754021000042391

Iyer, K.N., Germain, R., \& Frankwick, G.L. (2004). Supply chain B2B e-commerce and time-based delivery performance. International Journal of Physical Distribution \& Logistics Management, 34(8), 645-661. https://doi.org/10.1108/09600030410557776

Jackson, J.R. (1956). An extension of Johnson's results on job IDT scheduling. Naval Research Logistics (NRL), 3(3), 201-203. https://doi.org/10.1002/nav.3800030307

Kennerley, M., \& Neely, A. (2003). Measuring performance in a changing business environment. International Journal of Operations \& Production Management, 23(2), 213-229. https://doi.org/10.1108/01443570310458465

Lee, J., Lapira, E., Bagheri, B., \& Kao, H.A. (2013). Recent advances and trends in predictive manufacturing systems in big data environment Manufacturing Letters, 1(1), 38-41. https:/ / doi.org/10.1016/j.mfglet.2013.09.005

Morash, E.A., \& Clinton, S.R. (1998). Supply chain integration: customer value through collaborative closeness versus operational excellence. Journal of Marketing Theory and Practice, 6(4), 104-120.

https://doi.org/10.1080/10696679.1998.11501814

Mugwindiri, K., Nyemba, W.R., Madanhire, I., \& Mushonga, R. (2013). The Design of a Production Planning and Control System for a Food Manufacturing Company in a Developing Country, using Simulation. International Journal of Application or Innovation in Engineering and Management, 2(6), 116-125.

Nakajima, S. (1988). Introduction to TPM: Total Productive Maintenance.(Translation). Productivity Press, Inc., 1988, 129.

Oechsner, R., Pfeffer, M., Pfitzner, L., Binder, H., Müller, E., \& Vonderstrass, T. (2002). From overall equipment efficiency (OEE) to overall Fab effectiveness (OFE). Materials Science in Semiconductor Processing, 5(4), 333-339. https://doi.org/10.1016/S1369-8001(03)00011-8

Pakdil, F., \& Leonard, K.M. (2014). Criteria for a lean organisation: development of a lean assessment tool. International Journal of Production Research, 52(15), 4587-4607. https://doi.org/10.1080/00207543.2013.879614

Ponsignon, T., \& Mönch, L. (2014). Simulation-based performance assessment of master planning approaches in semiconductor manufacturing.Omega, 46, 21-35. https://doi.org/10.1016/j.omega.2014.01.005

Ramlan, R., Ngadiman, Y., Omar, S.S., \& Yassin, A.M. (2015). August. Quantification of machine performance through Overall Equipment Effectiveness. In Technology Management and Emerging Technologies (ISTMET), 2015 International Symposium on (pp. 407-411). IEEE

Razzak, M.A., Daley, G., \& Dismukes, J.P. (2002). Factory Level Metrics: Basis for Productivity Improvement. In Proceedings of the International Conference on Modeling and Analysis of Semiconductor Manufacturing (MASM2002) (158162).

Roser, C., Lorentzen, K., \& Deuse, J. (2014). Reliable shop floor bottleneck detection for flow lines through process and inventory observations. Procedia CIRP, 19, 63-68. https://doi.org/10.1016/j.procir.2014.05.020 
Rosenzweig, E.D., Roth, A.V., \& Dean, J.W. (2003). The influence of an integration strategy on competitive capabilities and business performance: an exploratory study of consumer products manufacturers. Journal of operations management, 21(4), 437-456. https:/ / doi.org/10.1016/S0272-6963(03)00037-8

Salegna, G.J., \& Park, P.S. (1996). Workload smoothing in a bottleneck job shop. International Journal of Operations \& Production Management, 16(1), 91-110. https://doi.org/10.1108/01443579610106382

Samad, M.A., Hossain, M.R., \& Major, S. (2012). Analysis of Performance by Overall Equipment Effectiveness of the CNC Cutting Section of a Shipyard, 2(11), 1091-1096.

Simons, D., Mason, R., \& Gardner, B. (2004). Overall vehicle effectiveness. International Journal of Logistics Research and Applications, 7(2), 119-135. https://doi.org/10.1080/13675560410001670233

Thürer, M., Stevenson, M., Silva, C., \& Qu, T., (2017). Drum-buffer-rope and workload control in High-variety flow and job shops with bottlenecks: An assessment by simulation. International Journal of Production Economics, 188, 116-127. https://doi.org/10.1016/j.ijpe.2017.03.025

Villarreal, B. (2012). The transportation value stream map (TVSM). European Journal of Industrial Engineering, 6(2), 216-233. https://doi.org/10.1504/EJIE.2012.045606

Villarreal, B., Sañudo, M., Vega, A., Macias, S., \& Garza, E. (2012). A Lean Scheme for Improving Vehicle Routing Operations. In Proceedings of the 2012 International Conference on Industrial and Operations Management (IEOM) (3-6).

Yuan, R., \& Graves, S.C. (2016). Setting optimal production lot sizes and planned lead times in a job shop. International Journal of Production Research, 54(20), 6105-6120. https://doi.org/10.1080/00207543.2015.1073859

Zammori, F., Braglia, M., \& Frosolini, M. (2011). Stochastic overall equipment effectiveness. International Journal of Production Research, 49(21), 6469-6490. https://doi.org/10.1080/00207543.2010.519358

Zammori, F. (2015). Fuzzy Overall Equipment Effectiveness (FOEE): capturing performance fluctuations through LR Fuzzy numbers. Production Planning \& Control, 26(6), 451-466. https://doi.org/10.1080/09537287.2014.920545

Zhou, J., Zhao, S., Li, P., Zhou, H., Zhang, Q., \& Shang, Z. (2009). February. Research on processes simulation and reconfiguration for piston production lines. In Computer Modeling and Simulation, 2009. ICCMS'09. International Conference on (49-52). IEEE. https://doi.org/10.1109/ICCMS.2009.13

Journal of Industrial Engineering and Management, 2020 (www.jiem.org)

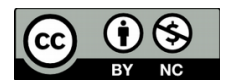

Article's contents are provided on an Attribution-Non Commercial 4.0 Creative commons International License. Readers are allowed to copy, distribute and communicate article's contents, provided the author's and Journal of Industrial Engineering and Management's names are included. It must not be used for commercial purposes. To see the complete license contents, please visit https://creativecommons.org/licenses/by-nc/4.0/. 